\title{
Treatment of chikungunya chronic arthritis: A systematic review
}

\author{
Gabriella Maria Pitt Gameiro Sales ${ }^{1}$, Izabel Crystine Pereira Barbosa ${ }^{1}$, Laura Maia Sampaio Canejo Neta ${ }^{1}$, \\ Paloma lopes de Melo ${ }^{1}$, Raphael de Azevedo leitão ${ }^{1}$, Hugo Moura de Albuquerque Melo²* (D \\ ${ }^{1}$ Medical Student, Universidade Federal de Pernambuco (UFPE), Caruaru, PE, Brazil \\ ${ }^{2} \mathrm{MD}$, Geriatrician, MSc in Palliative Care, and Assistant Professor at UFPE, Caruaru, PE, Brazil
}

\begin{abstract}
SUMmarY
Introduction: Chikungunya (CHIK) is a tropical arbovirus, transmitted by the female mosquito Aedes aegypti and Aedes albopictus. In Brazil, there have been cases reported since 2014. The initial manifestations of this virus are sudden onset high fever, headache, chills, rashes, myalgia and intense joint pain. Usually, CHIK presents the acute and chronic phases, the latter characterized by bilateral polyarthralgia, which can last for months or even years. During this period, autoimmune diseases can be triggered, making the picture even more complicated. Method: A systematic review was performed on the PubMed and Scielo databases in January 2017. Clinical trials, cohorts, case-control and case reports were included in the study. Expert opinions, societal consensuses and literary reviews were exclusion criteria. Studies were conducted in English, Spanish and Portuguese. The studies were descriptively analyzed and the data was grouped according to methodological similarity.

Results: Twenty-four (24) articles were selected and, in compliance with the inclusion and exclusion criteria, 18 were eliminated, with six studies remaining in the present review: five clinical trials and one case report.

Study conducted at Universidade Federal de Pernambuco, Caruaru, PE, Brazil

Article received: $3 / 21 / 2017$ Accepted for publication: $4 / 3 / 2017$

*Correspondence:

Curso Médico, Campus do Agreste Address: Av. Prof. Moraes Rego, 1235 Recife, PE - Brazil Postal code: 50670-901 hugo.amelo@ufpe.br

Conclusion: When the manifestations of CHIK become chronic and, the longer they last, more complications arise. Polyarthralgia can be immaterial, distancing individuals from their daily-life activities. Anti-inflammatory drugs (either steroid or not), in addition to immunosuppressants, homeopathy and physiotherapy are measures of treatment that, according to the literature, have been successful in relieving or extinguishing symptoms. However, it is fundamental that studies of CHIK treatment be further developed.
\end{abstract}

Keywords: Chikungunya Virus. Arthralgia. Arthritis.

\section{INTRODUCTION}

Chikungunya (CHIK) is a disease caused by the Chikungunya virus (CHIKV), an alphavirus belonging to the family Togaviridae, which is transmitted through the bite of infected Aedes aegypti and Aedes albopictus female mosquito. ${ }^{1,2}$ CHIK is considered a tropical disease because it circulates within the subtropical and tropical regions, with geographic distribution in the African continent, Southeast Asia and South America, with cases in Europe and North America occurring mainly in travelers. ${ }^{2,3}$ In 2013, the first case of local transmission in the Americas was reported in the Caribbean. In 2014, Brazil, together with other South American countries, such as Colombia,
Suriname and Paraguay, had already registered the local circulation of the virus. ${ }^{4}$ Symptomatic infection caused by this virus is usually marked by a sudden onset of fever, with a body temperature normally higher than $39^{\circ} \mathrm{C}$, headache, chills, conjunctivitis, rash, myalgia and severe joint pain, with or without swelling. ${ }^{1-5}$ Although CHIK may present with different clinical manifestations in the regions where the disease virus circulates, the presence of the debilitating polyarthralgia symptom causes the predictive value for CHIK to be greater than $80 \%{ }^{1,5}$

In general, CHIK has two phases: acute and chronic. During the acute phase, the main manifestations are high fever, headache, chills, nausea, vomiting, fatigue, back 
pain, myalgia and arthralgia. ${ }^{1,2}$ As for joint symptoms, there is variation from polyarthralgia to symmetrical polyarthritis; the most affected joints are wrist, metacarpal and interphalangeal joints, elbows, ankles, and knees. ${ }^{2,5,6}$

Arthralgia as standard does not present a defined course, but tends to be more intense in the morning, worsening with more intense physical activity. ${ }^{1}$ In the chronic phase, the manifestations are similar to those of the acute phase, including the symmetrical involvement of the joints. Joint pain that persists beyond recovery time is what characterizes this phase. It usually stays for two weeks but there is a possibility that polyarthralgia can last from weeks to years. ${ }^{1,3}$ Therefore, in the chronic phase, CHIKV can produce severe arthralgia and/or arthritis, lasting months to years after the initial infection, interfering with the individual's quality of life. ${ }^{3,7}$

Chronic arthralgia does not currently have an effective causal relationship with the initial CHIK virus infection, although there is an association between them. Possible causes of chronicity of arthralgia are: viral persistence, genetic predisposition, autoimmune disease induction, tissue damage directly caused by the virus and exacerbation of preexisting joint disease. ${ }^{3,8}$ In addition, disease severity in the acute phase is also related to the risk of developing chronic arthralgia in the chronic phase. Some parameters analyzed, which correlate with the chronicity of the symptoms, are the severity of joint pain and the presence of swelling in the joints. ${ }^{3}$

Thus, arthralgia that persists in the chronic phase of the disease is often debilitating and can lead to impairment in the individual's life, with cases in which patients continue with incapacitating arthritis, even affecting their mobility and requiring long-term treatment. ${ }^{5,9}$

Currently, there is no specific treatment for CHIK, although some drugs are used for this purpose, as well as therapeutic techniques. The objective of our study was to conduct a systematic review of the literature regarding the main types of current treatments for arthralgia in the chronic phase of chikungunya.

\section{Method}

The study was based on the Cochrane manual for the preparation of systematic reviews. ${ }^{10}$ The search for studies was done in the electronic databases PubMed and Scielo in January, 2017. To this end, the keywords "chikungunya and treatment and arthralgia" and "chikungunya and treatment and arthritis", available in the MeSH - Medical Subject Headings, were entered in both data platforms, without language restriction for articles. The research protocol used as inclusion criteria: clinical trial articles, cohort study, case-control, experimental, descriptive, case series and single case report, all published in the last ten years, excluding: literature reviews, consensuses of medical societies, expert opinion and articles of restricted access.

The articles identified by the initial search strategy had their titles and abstracts evaluated independently by two researchers, authors of this study, obeying the inclusion and exclusion criteria referring to the research protocol; there was no restriction to population groups, and only studies with humans that presented a relevant outcome for the subject were included. In cases where reading the abstracts was not enough to determine their eligibility according to defined inclusion criteria, the articles were read in full so that they could be included or excluded.

In order to extract information from the selected studies, an instrument was prepared, including the following information: authors, year of publication, methodological design, intervention protocol, intervention groups, sample, time and frequency, and outcome. From that point on, the studies were analyzed and interpreted descriptively and their data were presented based on methodological similarities, grouped according to the final conclusions.

\section{RESULTS}

To obtain the results, after the research based on the keywords established in the research protocol, 20 articles were selected in the PubMed platform and 4 in the Scielo, which referred to the proposed theme, totaling 24 articles. Of these, two were eliminated because they were duplicated, five because they did not constitute human studies, seven because they corresponded to literature reviews, two because they represented opinion articles, and two because they were not accessible for reading. Thus, six studies were included in our systematic review (Figure 1).

The studies selected for review of the literature were published between 2008 and 2016, with three studies conducted in India, ${ }^{9,11}$ Asia; one in Reunion Island, ${ }^{12}$ East Africa; one in the Dominican Republic, ${ }^{13}$ Central America; and one in Brazil,${ }^{14}$ South America.

As for characteristics of methodological design, five studies were clinical trials, three of them contemplating the population group between 12 and 80 years, ${ }^{11,12,15}$ while two did not describe the age of the sample group. ${ }^{9,14}$ In the case of clinical trials, treatment outcome results with the following types of drugs were assessed: steroidal and non-steroidal anti-inflammatory drugs (SAIDs and NSAIDs), disease-modifying antirheumatic drugs (DMARDs) such 


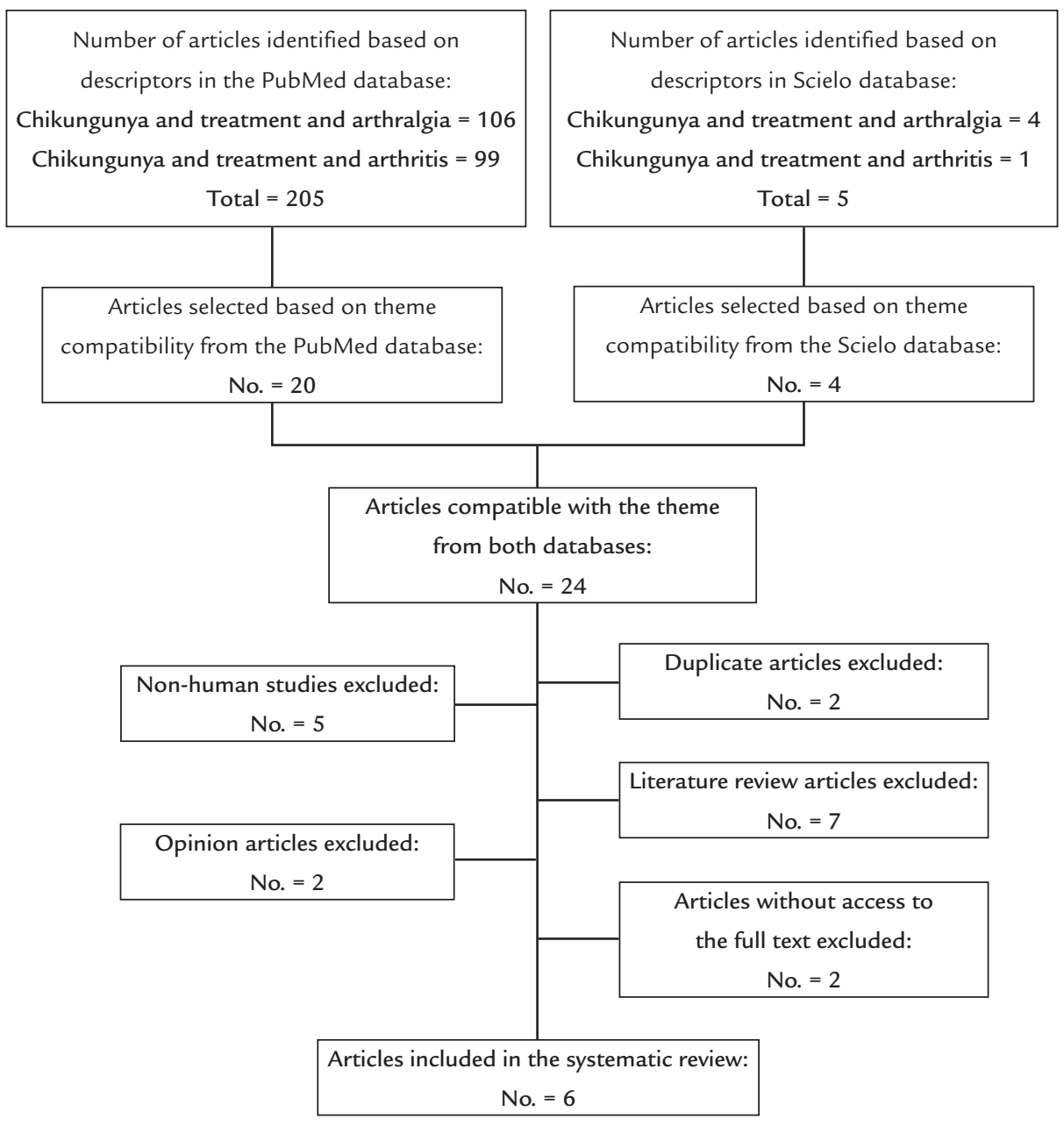

FIGURE 1 Flowchart for identification and selection of articles of systematic review on the treatment of arthralgia in the chronic phase

of chikungunya.

as hydroxychloroquine, chloroquine, ribavirin, immuno-modulators and homoeopathic substance (Table 1).

Another study, structured as a case report, presented a non-pharmacological strategy using ultrasound, TENS, and laser using a physiotherapeutic approach (Table 1). This study revealed the potential of such techniques in reducing the pain experienced by the patient reported, reflected in the decrease in the use of oral analgesics. ${ }^{14}$

Among the pharmacological approach studies analyzed (Table 2), two presented an evaluation for NSAIDs. In both cases, there was improvement in the symptoms of arthritis with arthralgia and edema after using this class of drug. The study conducted in Reunion Island reported an improvement in symptoms in $70 \%$ of patients after the use of NSAIDs; however, the doses, frequencies and period of administration were not reported, not even the drug. ${ }^{12}$
The study in the Dominican Republic, in turn, showed improvement of symptoms in $89 \%$ of patients who used NSAIDs, including: Naproxen with $550 \mathrm{mg}$ twice daily; celecoxib with $400 \mathrm{mg}$ daily, and etoricoxib with $90 \mathrm{mg}$ daily. ${ }^{13}$

The group studied in Reunion Island was also evaluated for the use of methotrexate, with improvement in symptoms in $75 \%$ of cases, and hydroxychloroquine, which did not present benefits. ${ }^{12}$ The study performed in the Dominican Republic showed a $72 \%$ improvement in the use of SAIDs such as prednisone at a dose of 5-7.5 mg daily and flazacort at a dose of $6 \mathrm{mg}$ daily. ${ }^{13}$

Chopra et al. ${ }^{11}$ conducted a double-blind randomized trial of patients who presented arthritis more than six weeks after CHIKV infection to assess the benefits of chloroquine over NSAID meloxicam. In the study, the authors found no statistical difference between the two drugs. ${ }^{11}$ 
TABLE 1 Stratification of studies, available from online databases, in January 2017.

\begin{tabular}{lllll} 
Author, year & Country & Design & Sample & Drugs used \\
\hline Javelle et al. ${ }^{12}$ & Reunion Island & Clinical trial & 159 , aged 16 to 80 years & SAIDs, methotrexate and hydroxychloroquine \\
\hline Chopra et al. $^{11}$ & India & Clinical trial & 70 adults & Chloroquine and meloxicam \\
\hline Wadhwani $^{15}$ & India & Clinical trial & 126 , aged 12 to 60 years & Homeopathy \\
\hline Ravichandran and Manian $^{9}$ & India & Clinical trial & 20 & Ribavirin \\
\hline Rosario et al. $^{13}$ & Dominican Republic & Clinical trial & 567 & NSAIDs and DMARDs \\
\hline Ribeiro et al. ${ }^{14}$ & Brazil & Case report & 1 & Physiotherapeutic approach \\
\hline
\end{tabular}

SAIDs: steroidal anti-inflammatory drugs; NSAIDs: non-steroidal anti-inflammatory drugs; DMARDs: disease-modifying antirheumatic drugs.

\section{TABLE 2 Detail of the studies with pharmacological approach January, 2017.}

\begin{tabular}{|c|c|c|c|c|}
\hline Author, year & jective & odology & Detailed intervention & e \\
\hline et al. ${ }^{12}$ & $\begin{array}{l}\text { To analyze and evaluate the } \\
\text { clinical and therapeutic } \\
\text { spectrum effective for } \\
\text { rheumatic disorders after } \\
\text { CHIKV }\end{array}$ & $\begin{array}{l}\text { A retrospective clinical study that } \\
\text { evaluated medical records of } \\
\text { patients with rheumatic or skeletal } \\
\text { muscle pain after CHIKV infection } \\
\text { treated at a rheumatology clinic } \\
\text { over } 6 \text { years with the identification } \\
\text { of clinical and laboratory data } \\
\text { before and after the treatment }\end{array}$ & $\begin{array}{l}\text { SAIDs: unspecified dose } \\
\text { Methotrexate: } 15 \mathrm{mg} / \text { week } \\
\text { Hydroxychloroquine: } \\
200 \mathrm{mg} / \text { day }\end{array}$ & $\begin{array}{l}\text { Patients treated with SAIDs } \\
\text { presented a positive } \\
\text { therapeutic response in } 70 \% \text { of } \\
\text { the cases; treated with } \\
\text { methotrexate, } 75 \% \text {. } \\
\text { Hydroxychloroquine did not } \\
\text { present benefits }\end{array}$ \\
\hline Chopra et al. ${ }^{11}$ & $\begin{array}{l}\text { To evaluate whether } \\
\text { chloroquine has greater } \\
\text { benefits in relation to } \\
\text { meloxicam for the treatment } \\
\text { of musculoskeletal pain and } \\
\text { post-CHIKV arthritis }\end{array}$ & $\begin{array}{l}\text { A prospective, randomized, } \\
\text { double-blind clinical trial } \\
\text { evaluating patients with arthritis } \\
\text { for more than } 6 \text { weeks after } \\
\text { CHIKV infection }\end{array}$ & $\begin{array}{l}\text { Chloroquine: } 250 \mathrm{mg} / \text { day } \\
\text { Meloxicam: } 7.5 \mathrm{mg} / \text { day }\end{array}$ & $\begin{array}{l}\text { There was no difference in } \\
\text { efficacy between the groups } \\
\text { using chloroquine and } \\
\text { meloxicam }\end{array}$ \\
\hline Wadh & $\begin{array}{l}\text { To observe the effect of } \\
\text { homeopathic therapy in the } \\
\text { acute phase and post- } \\
\text { CHIKV chronic arthritis }\end{array}$ & $\begin{array}{l}\text { A prospective clinical trial that } \\
\text { evaluated patients in the acute } \\
\text { phase of chikungunya and with } \\
\text { chronic arthritis after CHIKV }\end{array}$ & $\begin{array}{l}\text { The homeopathic medication } \\
\text { was used at initial doses three } \\
\text { times a day, being reduced to } \\
\text { two and one, with improvement }\end{array}$ & $\begin{array}{l}90 \% \text { of cases of chronic } \\
\text { arthritis achieved cure after an } \\
\text { average time of } 32.5 \text { days }\end{array}$ \\
\hline $\begin{array}{l}\text { Ravichandran } \\
\text { and Manian }{ }^{9}\end{array}$ & $\begin{array}{l}\text { To evaluate the effect of } \\
\text { the antiviral drug ribavirin } \\
\text { on the clinical outcome of } \\
\text { patients with post-CHIKV } \\
\text { arthritis }\end{array}$ & $\begin{array}{l}\text { Prospective clinical trial evaluating } \\
\text { patients with post-CHIKV arthritis. } \\
\text { One group of patients used the } \\
\text { drug for } 7 \text { days, and was } \\
\text { reevaluated after } 4 \text { weeks, } \\
\text { while the control group used } \\
\text { analgesics freely }\end{array}$ & $\begin{array}{l}\text { Ribavirin group: } 200 \text { mg twice } \\
\text { daily for } 7 \text { days. } \\
\text { Control group: analgesics, } \\
\text { if necessary }\end{array}$ & $\begin{array}{l}\text { At the end of } 4 \text { weeks, the } \\
\text { ribavirin group showed } \\
\text { improvement in walking } \\
\text { capacity and edema in } 70 \text { and } \\
80 \% \text { of the cases, respectively, } \\
\text { and relapse of pain in } 30 \% \text {, } \\
\text { while the control group } \\
\text { presented improvement in } \\
\text { walking capacity and edema in } \\
30 \text { and } 60 \% \text {, respectively, and } \\
70 \% \text { of recurrence of pain }\end{array}$ \\
\hline Rosario et al. ${ }^{13}$ & $\begin{array}{l}\text { To compare the therapeutic } \\
\text { difference between patients } \\
\text { from the general population } \\
\text { and those previously } \\
\text { diagnosed with rheumatoid } \\
\text { arthritis, after CHIKV } \\
\text { infection events }\end{array}$ & $\begin{array}{l}\text { A retrospective clinical study } \\
\text { evaluated the therapeutic use in a } \\
\text { group of patients without } \\
\text { rheumatic complaints prior to } \\
\mathrm{CHIKV} \text { infection and patients } \\
\text { undergoing treatment for } \\
\text { rheumatoid arthritis after CHIKV }\end{array}$ & $\begin{array}{l}\text { Naproxen: } 550 \mathrm{mg} \text { twice daily; } \\
\text { celecoxib: } 400 \mathrm{mg} / \text { day; } \\
\text { etoricoxib: } 90 \mathrm{mg} / \text { day; } \\
\text { prednisone: } 5-7.5 \mathrm{mg} / \text { day; } \\
\text { deflazacort: } 6 \mathrm{mg} / \text { day }\end{array}$ & $\begin{array}{l}\text { The population group that } \\
\text { had no previous rheumatic } \\
\text { complaints had } 89 \% \\
\text { improvement with NSAIDs, } \\
72 \% \text { with SAIDs }\end{array}$ \\
\hline
\end{tabular}


Similarly, the benefits of ribavirin in relation to the control group were evaluated. ${ }^{13}$ Patients were treated with ribavirin $200 \mathrm{mg}$ twice daily for seven days, and were evaluated four weeks after therapy, while the control group used analgesics freely during the period. One of the main findings of the study was that after four weeks, the ribavirin group showed improvement in walking ability in $70 \%$ of patients, reduction of edema in $80 \%$ and recurrence of pain in $30 \%$, while the control group showed improvement in walking capacity in 30\%, edema in $60 \%$ and recurrence of pain in $70 \%$ of patients. ${ }^{13}$

There was also a prospective clinical study using homeopathic approach, in which Wadhwan ${ }^{15}$ evaluated the use of homeopathic medication in the acute phase of chikungunya and chronic arthritis caused by the infection. One of the results that could be observed was that, in addition to the benefit in the acute phase, the therapy produced cure of the symptoms of arthritis in $90 \%$ of the evaluated cases, with a mean recovery time of 32.5 days. ${ }^{15}$

\section{Discussion}

CHIK is a disease that can present with two phases, acute and late. The acute phase is the period in which symptomatic patients generally report abrupt onset, often characterized by high fever, polyarthralgia, back pain, headache and fatigue. ${ }^{14}$ The late phase usually manifests with arthralgia or musculoskeletal pain, with more frequent and lasting signs, interfering for weeks or months, and sometimes for years in the patients' quality of life. ${ }^{1}$ Despite the various therapeutic regimens available for CHIK, $40 \%$ of patients progress with chronic pain and compromised quality of life, ${ }^{14}$ making it critical to research on late-phase therapy.

The management of patients with chronic inflammatory rheumatic disease after CHIKV has been reported and appears to bring benefits with the use of methotrexate (MTX). Ribeiro et al. ${ }^{14}$ report that MTX may be used at an average dose of $15 \mathrm{mg}$ per week, given the similarities between arthralgia associated with chronic CHIKV and rheumatoid arthritis (RA). In cases of RA after CHIKV, clinical features such as joint destruction and positivity of rheumatoid factor have been described, but in a limited number of CHIK post-fever cases. ${ }^{2}$

Castro et al. ${ }^{1}$ argue that the use of MTX is justified by the observation of the presence of monocytes and macrophages in the synovial tissue of chronic patients, perhaps due to the persistence of the virus in this site. Goupil and Mores ${ }^{3}$ mention the benefit of treatment of up to six months with MTX and hydroxychloroquine, so that in some cases, magnetic resonance imaging (MRI) showed an improvement in the severity of joint edema, pain and tendon involvement for 15 months after the beginning of treatment.

Another drug that is gaining ground in the treatment of the chronic phase of CHIKV is ribavirin, which is a synthetic nucleoside analog that inhibits a wide range of RNA and DNA viruses. The mechanism of action of this drug is not yet fully understood and may be different for different groups of viruses. In studies by Ravichandran and Manian, ${ }^{9}$ ribavirin was used in a group of patients with chronic, incapacitating arthralgia due to CHIKV. The analgesic was discontinued and ribavirin started at $200 \mathrm{mg}$ twice daily for seven days. All patients reported improvement of pain; however, this study presented as a limitation a small number of people, as well as not being a planned study, since the patients were distributed randomly, making it impossible to compare it with a control group.

Chloroquine phosphate, which has been reported to be effective in the treatment of chronic CHIKV arthritis, is also discussed.${ }^{16}$ However, in a clinical trial by Chopra et al., ${ }^{11}$ no differences were observed between the placebo group and the treatment group in CHIKV-infected patients. It should be emphasized that chloroquine exhibits antiviral and anti-inflammatory properties that deserve attention in the clinical management of some viral diseases. ${ }^{16}$

There is also a study by Crostein and Sunkureddi ${ }^{17}$ that refers to colchicine, which is a drug used since the $18^{\text {th }}$ century in the treatment of acute gouty arthritis and has anti-inflammatory effects. Colchicine is an antimitotic alkaloid that disrupts cytoskeletal assembly, intracellular signaling in neutrophils and inhibits neutrophil migration by decreasing the expression of neutrophil adhesion molecules. In a case report by Redel, ${ }^{18}$ this drug was used at the dose of $0.6 \mathrm{mg}$ per day in a patient with persistent arthralgia in the ankle and left wrist, with bilateral edema in the lower extremities. After 2 to 3 days, the patient had already seen resolution of the swelling and improvement of arthralgia. In two months of use, the symptoms were resolved. The patient continued to use colchicine for six months, and had no adverse events. Therefore, the case report shows that the patient was free of symptoms for eight months. Colchicine is suggested to be a therapeutic option for cases of persistent arthralgia due to CHIKV, despite treatment with non-steroidal anti-inflammatory drugs.

In addition to pharmacological treatment for rheumatic manifestations of the late phase of CHIKV, Ribeiro et al. ${ }^{14}$ report the efficacy of ten sessions of continuous ultrasound with a frequency of $1 \mathrm{MHz}$ applied once a day, from Monday to Friday, followed by infrared laser at the 
dose of $4 \mathrm{~J}$ and $3 \mathrm{~s}$ per point, and TENS-burst with a pulse width of $250 \mathrm{uS}$ and frequency of $2 \mathrm{~Hz}$. This association showed a significant post-intervention improvement for quality of life assessed by SF-36 (Medical Outcomes Study 36) and visual analogue scale (VAS) scores. The study by Ribeiro et al. ${ }^{14}$ is presented as a justification for the effectiveness of the physiotherapeutic treatment, since the application of continuous ultrasound transmits the heat by convection, causing an increase in blood flow through vasodilation, capillary permeability, speed of muscle contraction, nerve conduction, cellular metabolic rate, and extensibility of collagen. TENS, transcutaneous electrical current, stimulates large afferent sensory fibers that block the primary nociceptive fibers releasing endorphins and decreasing pain. The light from low-power laser therapy produces photochemical reactions within cells that activate enzymes, at the cellular level, with the ability to increase mitochondrial function and ATP synthesis, increasing cell proliferation and accelerating the healing process. ${ }^{14}$ But, as reported in the study itself, the sessions are time-consuming, especially considering that patients usually have complaints in several joints, making the sessions longer and rendering it unfeasible to treat a larger numbers of patients. Also, the study is a case report, requiring more research with a larger sample.

Another alternative to traditional pharmacological treatment, in addition to the physiotherapeutic treatment already mentioned, is homeopathy. In a study by Wadhwani, ${ }^{15}$ both acute and chronic phase patients were studied, focusing on the latter. Twenty (20) people with chronic chikungunya arthritis were selected and $90 \%$ of the cases achieved full recovery after the average of 32.5 days.

The treatment was done in an individualized manner, i.e. the homeopathic remedies used were not the same for the 20 patients, and included: Lycopodium, Arnica montana, Rhus toxicodendron followed by Bryonia alba, Bryonia alba followed by Rhus toxicodendron, Ignatia amara, Calcarea carbonica, Calcarea phosphorica, Lachesis Muta, Natrum muriaticum, Phytolacca decandra and radium bromide. Patients in this study did not return to traditional treatment, and homeopathic prescription is an alternative to be further explored. ${ }^{15}$

\section{Conclusion}

There was a long-term indication of the use of methotrexate and hydroxychloroquine for treatment, but they did not always resolve arthralgia in the chronic phase of CHIK. Thus, other drugs such as ribavirin and colchicine, and the maintenance of analgesics and anti-inflammatory drugs, judiciously used, have been proposed as alternatives (Figure 2). Physiotherapeutic treatment has shown some satisfactory results through electrothermal therapy. Homeopathy has also been an alternative in therapeutics (Figure 3).

But investigations must be intensified, since the literature on CHIK is still scarce. In addition, it is important

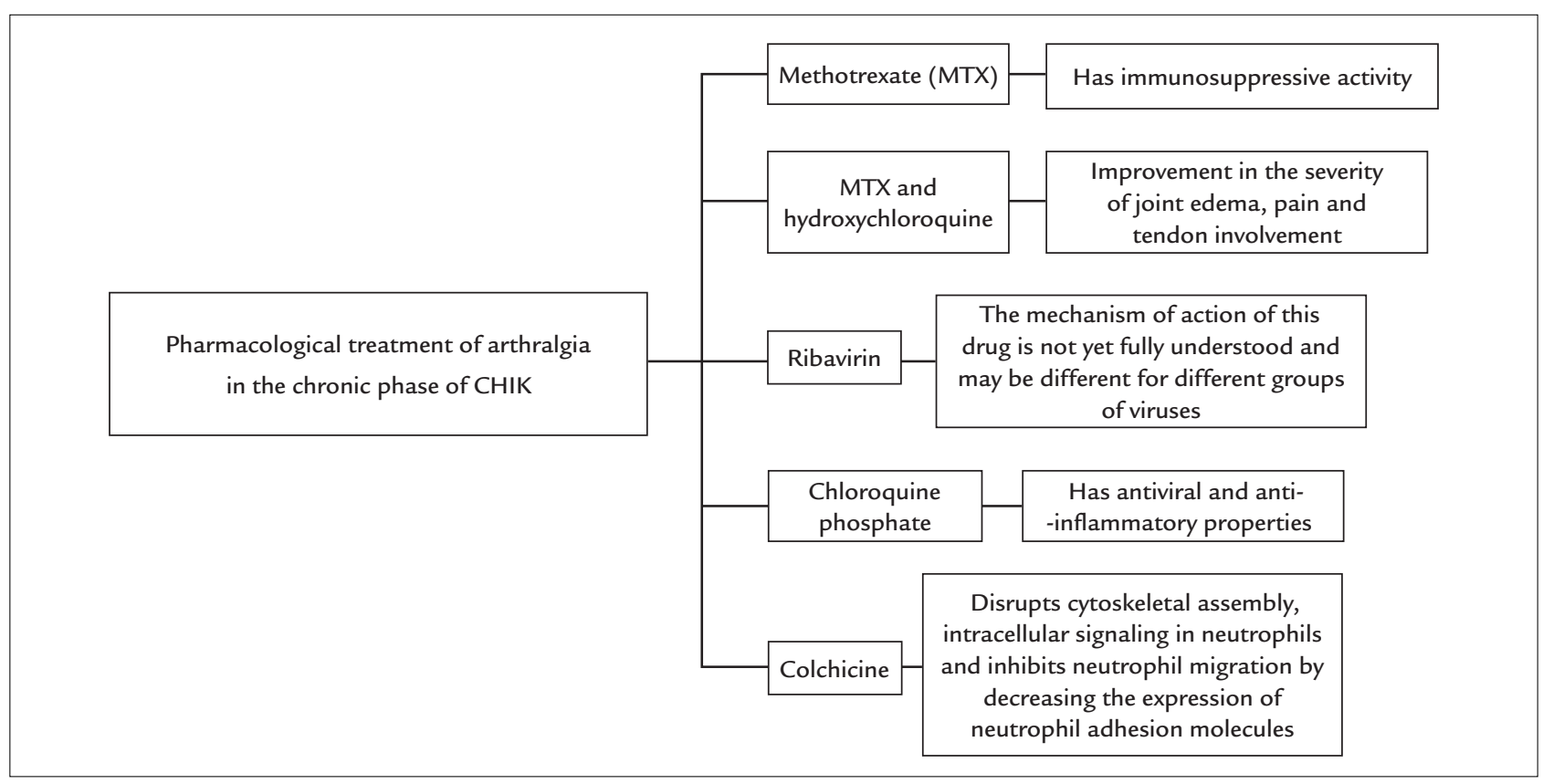

FIGURE 2 Conceptual map of pharmacological treatment of arthralgia in chikungunya. 


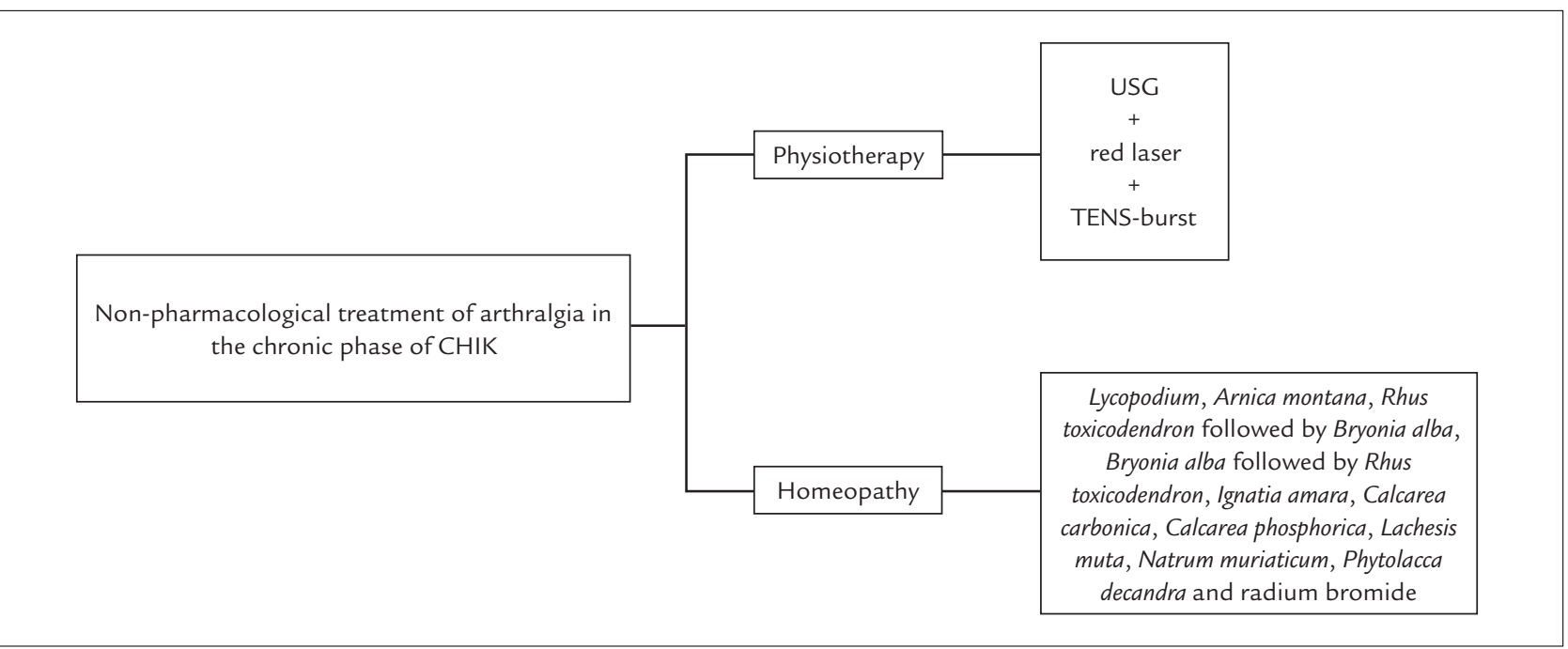

FIGURE 3 Conceptual map of non-pharmacological treatment of arthralgia in chikungunya.

to emphasize to the public the need for disease prevention, through educational campaigns and more vigorous supervision by the competent bodies.

\section{Conflict Of InTERest}

The authors declare no conflict of interest.

\section{Resumo}

Tratamento de artralgia crônica da chikungunya: uma revisão sistemática

Introdução: A chikungunya é uma arbovirose tropical, transmitida pela fêmea dos mosquitos Aedes aegypti e Aedes albopictus. No Brasil, existem casos relatados desde 2014. As manifestações iniciais dessa virose são: febre alta de início súbito, cefaleia, calafrios, erupções cutâneas, mialgia e dor articular intensa. Normalmente, a chikungunya apresenta as fases aguda e crônica, sendo a última caracterizada pela poliartralgia bilateral, que pode durar meses e até anos. Durante esse período, doenças autoimunes podem ser desencadeadas, tornando o quadro ainda mais complicado.

Método: Foi realizada uma revisão sistemática nos bancos de dados PubMed e Scielo em janeiro de 2017. Ensaios clínicos, coortes, casos-controle e relatos de caso foram incluídos na pesquisa. Opiniões de especialista, consensos de sociedades e revisões literárias foram critérios de exclusão. Foram avaliados estudos nas línguas inglesa, espanhola e portuguesa. Os estudos foram analisados descritivamente, e os dados agrupados, conforme semelhança metodológica.
Resultados: Foram selecionados 24 artigos; em obediência aos critérios de inclusão e exclusão, 18 foram eliminados, restando seis estudos na presente revisão: cinco ensaios clínicos e um relato de caso.

Conclusão: Quando as manifestações da chikungunya se tornam crônicas, quanto mais tempo duram, mais complicações surgem. A poliartralgia pode ser incapacitante, afastando os indivíduos das suas atividades de vida diária. Anti-inflamatórios (esteroides ou não), somados a imunossupressores, homeopatia e fisioterapia são medidas de tratamento que, conforme a literatura, têm alcançado êxito no alívio ou na extinção dos sintomas. Todavia, é fundamental que os estudos do tratamento da chikungunya sejam mais aprofundados.

Palavras-chave: Vírus Chikungunya. Artralgia. Artrite.

\section{REFEREnCES}

1. Castro APCR, Lima RA, Nascimento JS. Chikungunya: vision of the pain clinician. Rev Dor. 2016; 17(4):299-302.

2. Bouquillard E, Combe B. A report of 21 cases of rheumatoid arthritis following Chikungunya fever. A mean follow-up of two years. Joint Bone Spine. 2009; 76(6):654-7.

3. Goupil BA, Mores CN. A review of Chikungunya virus-induced arthralgia: clinical manifestations, therapeutics, and pathogenesis. Open Rheumatol J. 2016; 10:129-40.

4. Lima-Camara TN. Emerging arboviruses and public health challenges in Brazil. Rev Saúde Pública. 2016; 50:36.

5. Weaver SC, Lecuit M. Chikungunya virus and the global spread of a mosquitoborne disease. N Engl J Med. 2015; 372(13):1231-9.

6. Morens DM, Fauci AS. Chikungunya at the door - déjà vu all over again? N Engl J Med. 2014; 371(10):885-7.

7. Honório NA, Câmara DC, Calvet GA, Brasil P. Chikungunya: an arbovirus infection in the process of establishment and expansion in Brazil. Cad Saúde Pública. 2015; 31(5):906-8. 
8. McCarthy MK, Morrison TE. Chronic chikungunya virus musculoskeletal disease: what are the underlying mechanisms? Future Microbiol. 2016; 11(3):331-4.

9. Ravichandran R, Manian M. Ribavirin therapy for Chikungunya arthritis. J Infect Dev Ctries. 2008; 2(2):140-2.

10. Higgins JPT, Green S. Cochrane handbook for systematic reviews of interventions. Version 5.0.2. Melbourne: The Cochrane Collaboration; 2008.

11. Chopra A, Saluja M, Venugopalan A. Effectiveness of chloroquine and inflammatory cytokine response in patients with early persistent musculoskeletal pain and arthritis following Chikungunya virus infection. Arthritis Rheumat. 2014; 66(2):319-26.

12. Javelle E, Ribera A, Degasne I, Gaüzère BA, Marimoutou C, Simon F. Specific management of post-chikungunya rheumatic disorders: a retrospective study of 159 cases in Reunion Island from 2006-2012. PLoS Negl Trop Dis. 2015; 9(3):e0003603.
13. Rosario V, Munoz-Louis R, Valdez T, Adames S, Medrano J, Paulino I, et al. Chikungunya infection in the general population and in patients with rheumatoid arthritis on biological therapy. Clin Rheumatol. 2015;34(7):1285-7.

14. Ribeiro AMBM, Pimentel CM, Guerra ACCG, Lima MRO. Physiotherapeutic approach on the late phase of chikungunya: a case report. Rev Bras Saúde Matern Infant. 2016; 16(Suppl 1):S57-62.

15. Wadhwani GG. Homeopathic drug therapy. Homeopathy in Chikungunya fever and post-Chikungunya chronic arthritis: an observational study. Homeopathy. 2013; 102(3):193-8.

16. Savarino A, Cauda R, Cassone A. On the use of chloroquine for chikungunya Lancet Infect Dis. 2007; 7(10):633.

17. Cronstein BN, Sunkureddi P. Mechanistic aspects of inflammation and clinical management of inflammation in acute gouty arthritis. J Clin Rheumatol. 2013; 19(1):19-29.

18. Rendel H. A case of chikungunya virus induced arthralgia responsive to colchicine. Open Forum Infect Dis. 2016; 3(2):ofw114. 